\author{
Я. М. Тютюнник, старший судовий експерт \\ сектору товарознавчих та гемологічних досліджень \\ відділу товарознавчих, гемологічних, економічних, \\ будівельних, земельних досліджень та оціночної діяльності, \\ Сумський науково-достідний експертно- \\ криміналістичний центр МВС Украӥни, м. Суми \\ ORCID: https://orcid.org/0000-0002-6968-9796
}

\title{
ОСОБЛИВОСТІ ВИЗНАЧЕННЯ ВАРТОСТІ ЗЕРНОВИХ КУЛЬТУР ПІД ЧАС СУДОВОЇ ТОВАРОЗНАВЧОЇ ЕКСПЕРТИЗИ
}

\begin{abstract}
Mema статті полягає у розробленні на основі комплексного аналізу теоретичних положень, нормативно-правових актів і систем технічного регулювання пропозицій і практичних рекомендації щодо визначення вартості зернових культур під час судової товарознавчої експертизи. Методологія. Достовірність отриманих результатів і висновків забезпечено комплексом загальнонаукових і спеціальних методів пізнання. Так, порівняльно-правовим методом досліджено основні підходи до нормативної регламентації особливостей обігу зернових культур, унормування їх якості; системно-структурним з'ясовано сутність поняття та характеристики якості зерна; методами аналізу і синтезу визначено та досліджено особливості класифікації зернових культур за різними ознаками; за допомогою методу узагальнення виокремлено й охарактеризовано чинники, які впливають на вартість зерна і на які експерт має зважати, вирішуючи завдання судової товарознавчої експертизи; аналітичні методи дозволили сформулювати висновки за результатами дослідження. Наукова новизна. Систематизовано та обгрунтовано основні особливості визначення вартості зернових культур під час судової товарознавчої експертизи в контексті застосування спеціальних знань. Класифікацію зернових культур за призначенням уточнено двома позиціями - зерно для експортування та насіння (посівний матеріал). Висновки. Нормативно-правову базу, що врегульовує обіг сільськогосподарської, зокрема й зернової, продукції, становлять закони України та підзаконні нормативно-правові акти, а систему технічного регулювання - національні стандарти України, певною мірою гармонізовані з міжнародними вимогами, технічні регламенти, процедури підтвердження відповідності щодо конкретного виду зерна або насіння, що потребують подальшого узгодження. 3’ясовано особливості визначення вартості зернових культур під час судової товарознавчої експертизи, що грунтуються на застосуванні спеціальних товарознавчих й інших знань. Схарактеризовано та систематизовано чинники, які зумовлюють особливості визначення вартості зернових культур під час судової товарознавчої експертизи. У процесі викладу основного матеріалу сформульовано деякі пропозиції і практичні рекомендації щодо визначення вартості зернових культур під час судової товарознавчої експертизи, які можуть становити підгрунтя для розроблення відповідних методик і методичних рекомендацій.

Ключові слова: судова товарознавча експертиза; спеціальні знання; спеціальні товарознавчі знання; сільськогосподарська продукція; зернові культури; показники якості зерна; посівний матеріал; класифікація; умови постачання; зберігання зерна; вартість.
\end{abstract}

\section{Вступ}

На міжнародному аграрному ринку зерно заслужено вважається стратегічно важливим товаром, який не лише гарантує продовольчу безпеку, а й слугує стабільним джерелом доходів в усьому світі. Зерно $є$ одним із найпоширеніших товарів як світового, так і внутрішнього ринку сільськогосподарської продукції, а зерновий ринок - чи не найбільш досконалий і прогнозований у світі. Зернові культури як грунтовна галузь рослинництва становлять основу харчування людини, а також $є$ необхідною кормовою базою для тваринництва, вагомою часткою експорту країн. В Україні експорт зернових культур - одна з основних складових валютних надходжень до державного бюджету. Його обсяги, що постійно нарощуються, 2019 р. учетверо перевищили показник 2010 р. і досягли 56,7 млн т (Ukraina protiahom desiaty rokiv, 2020).
Водночас спостерігається збільшення правопорушень, пов'язаних із викраденням сільськогосподарської, у тому числі зернової, продукції у фізичних та юридичних осіб. Відповідно збільшується й кількість судових товарознавчих експертиз, серед досліджуваних питань яких - визначення вартості такої продукції, що й зумовлює актуальність обраної тематики.

Теоретичне підгрунтя дослідження становлять праці таких науковців, як В. І. Бойко, T. М. Гайдук, П. І. Гайдуцький, Д. П. Ізергін, I. В. Кобута, О. І. Коркуна, 3. П. Ніколаєва, В. Ю. Протасов, Л. С. Раужина, А. М. Рукосуєв, П. Т. Саблук, В. П. Ситник, В. С. Смирнов, А. І. Усіна, Л. М. Худолій, О. М. Шпичак та ін.

Проблеми використання спеціальних товарознавчих знань у різні періоди вивчали, зокрема, В. В. Архіпов, А. І. Олійник, I. А. Петрова, 
В. В. Полупан, О. П. Снігерьов, О. В. Шевченко.

Останнім часом фахівці порушували різні питання, серед яких підвищення якості сільськогосподарських культур, вплив умов зберігання на їхню якість, визначення показників якості зерна, його дефектності, класифікація за різними ознаками, збільшення врожайності тощо (see, in particular, Podpriatov, Skaletska, Senkov, \& Khylevych, 2002; Herman, \& Marenych, 2013; Shakalii, 2013; Havrylenko, Khomitska, \& Zahorulko, 2016; Zhukov, \& Ponomarenko, 2018; Yurkovska, Ovsiannykova, Yevdokymova, Valevska, \& Sokolovska, 2019), а також зважання на чинник природних ресурсів під час визначення багатофакторної продуктивності сільського господарства (Lesniak, 2019); актуальні питання судової товарознавчої експертизи: дефекти товарів та їх вплив на визначення вартості (Shytova, \& Sobakar, 2019); ідентифікація товарів та визначення фальсифікації продукції під час судової товарознавчої експертизи (Liapun, \& Kovalenko, 2020); актуальні проблеми вітчизняної судової товарознавчої експертизи (Zaiats, Yarovyi, \& Bednarchuk, 2019); теоретичні та методологічні аспекти судової товарознавчої експертизи (Buzyna, \& Kravchenko, 2020); особливості формування попиту у моделюванні ланцюгів постачання зернових культур (Kotenko, 2020); можливості судової товарознавчої експертизи в межах кримінального провадження (Olefir, 2020).

Іноземні колеги висвітлювали окремі аспекти зберігання зернових культур (Grain crop drying, handling and storage, 2011); питання грунтовної систематизації зернових культур (Неуnе, 2020); останні досягнення у дослідженні зернових культур (Hussain, Igbal, Khan, \& Shah, 2020); чинники, що впливають на продовольчу безпеку країн (FAO, 2020, Jul.), тощо.

А втім, віддаючи належне різноманітності та повноті проведених цими та іншими науковцями і практиками досліджень, особливості визначення вартості зернових культур під час судової товарознавчої експертизи в контексті застосування спеціальних знань потребують грунтовного розгляду.

\section{Мета й завдання дослідження}

Мета статті - розробити на основі комплексного аналізу теоретичних положень, нормативно-правових актів і систем технічного регулювання пропозиції і практичні рекомендації щодо визначення вартості зернових культур під час судової товарознавчої експертизи.

Для досягнення цієї мети потрібно виконати такі завдання:

проаналізувати нормативно-правову базу, що врегульовує обіг сільськогосподарської, зокрема й зернової, продукції; уточнити класифікацію зернових культур;

з'ясувати особливості визначення вартості зернових культур під час судової товарознавчої експертизи;

схарактеризувати та систематизувати чинники, які зумовлюють особливості визначення вартості зернових культур під час судової товарознавчої експертизи;

сформулювати пропозиції і практичні рекомендації щодо визначення вартості зернових культур під час судової товарознавчої експертизи.

\section{Виклад основного матеріалу}

В Україні обіг сільськогосподарської, зокрема й зернової, продукції внормовано законами України (key among them: Pro derzhavne rehuliuvannia importu silskohospodarskoi produktsii, 1997; Pro zerno ta rynok zerna $v$ Ukraini, 2002; Pro nasinnia $i$ sadyvnyi material, 2002; Pro derzhavnu pidtrymku silskoho hospodarstva Ukrainy, 2004) і деталізовано підзаконними нормативно-правовими актами. Систему технічного регулювання становлять національні стандарти України, певною мірою гармонізовані з міжнародними та європейськими вимогами (Nasinnia silskohospodarskykh kultur. Sortovi ta posivni yakosti. Tekhnichni umovy: DSTU 2240-93, 1994; Pshenytsia. Tekhnichni umovy: DSTU 3768:2019, 2019), а також технічні регламенти, процедури підтвердження відповідності щодо конкретного виду зерна або насіння.

Група зернових культур, за сучасною класифікацією (Usina, 2012, s. 39; Korkuna, Demichkovskyi, \& Tsilnyk, 2019, s. 48), об’єднує такі ботанічні родини:

злакові - пшениця, жито, тритикале, ячмінь, овес, кукурудза, просо, сорго, рис;

зернобобові (бобові) - горох, квасоля, боби, соя, чечевиця, нут, чина;

гречкові - гречка.

За терміном сівби вирізняють:

озимі - пшениця, жито, ячмінь;

ярові - пшениця, жито, ячмінь, рис, просо, овес, кукурудза.

На внутрішньому й міжнародному ринках зерно за призначенням класифікують як продовольче, фуражне, технічне та насінне (Hordiienko, \& Likhonina, 2008, s. 7). Інші фахівці (Usina, 2012, s. 39, 41; Korkuna, Demichkovskyi, \& Tsilnyk, 2019, s. 50; Heyne, 2020) виокремлюють продовольче (для виробництва харчових продуктів, наприклад борошна та круп); технічне (сировина для промислової переробки, наприклад на спирт, біопаливо, солод тощо); фуражне (для виготовлення корму для худоби).

При цьому, убачається, цей перелік, з огляду на розвиток міжнародної торгівлі (Porivnialnyi 
analiz, 2021) і зважаючи на те, що сільськогосподарські культури становлять основу експорту нашої країни, варто уточнити позиціями, як-от: зерно для експортування та насіння (посівний матеріал).

Насіння використовується лише для сівби $\mathrm{i}$ за законодавством України (Pro nasinnia i sadyvnyi material: Zakon Ukrainy, 2002, st. 15) уводиться в обіг після сертифікації - комплексу заходів, спрямованих на визначення сортових і посівних якостей із метою документального підтвердження відповідності вимогам законодавства у сфері насінництва та розсадництва. Сертифікат на насіння - документ про відповідність, що засвідчує сортові або посівні якості, окремо на кожну партію насіння (контрольну одиницю) видає ДП «Державний центр сертифікації та експертизи сільськогосподарської продукції».

Сортові та посівні якості насіння зернових культур регламентовані загальним стандартом ДСТУ 2240-93 «Насіння сільськогосподарських культур. Сортові та посівні якості. Технічні умови» (Nasinnia silskohospodarskykh kultur. Sortovi ta posivni yakosti. Tekhnichni umovy: DSTU 2240-93, 1994) та окремими стандартами, що поширюються на конкретну культуру.

Уніфікованих світових товарних класифікацій не існує, як, власне, й загальних стандартів на сільськогосподарську продукцію, у тому числі зерно (чинні міжнародні специфікації ISO 7970:2000 i ISO 11051:1994 та стандарт CODEX STAN 199. 1995 на різновиди пшениці - м'яка і тверда).

Тому слід зважати (Syrotiuk, 2010; Hlupak, 2017) на особливості стандартів, чинних як в країнах-продавцях, так і в країнах-покупцях зерна, а також основні технологічно важливі показники якості і методи їх визначення.

Наприклад, у країнах Європейського Союзу чинні власні регламенти, директиви, технічні умови на сільськогосподарську продукцію, зокрема й зерно. Грунтуються вони на біохімічних показниках якості та допустимому рівні домішок, за якими зерно поділяють на продовольче та фуражне. Основними показниками якості зерна в цих країнах є вміст білка, число падіння, натура. Відповідно будь-яка партія зерна - будь-яка кількість однорідного за якістю зерна, посвідченого одним документом про якість і призначеного для одночасного приймання, здавання, відвантаження чи зберігання в одній ємкості, з відхиленням від цих регламентів хоча $б$ за одним показником автоматично вважається фуражним.

Сьогодні, варто констатувати, якість вітчизняного зерна не відповідає міжнародним вимогам. У стандартах на зернові культури застосовуються нормативні посилання на застарілі стандарти гру- пи ГОСТ, зокрема на методи визначення якості зерна. Зарубіжні імпортери визнають результати аналізу тільки від лабораторій, що мають міжнародний сертифікат за типом GAFTA, ICUMSA або FOSFA (Yaki vymohy do eksportnoi pshenytsi, 2021). Новий національний стандарт України ДСТУ 3768:2019 «Пшениця. Технічні умови» (Pshenytsia. Tekhnichni umovy: DSTU 3768:2019, 2019) остаточно ситуації не виправив. За окремими біохімічними показниками якості та допустимого рівня домішок вітчизняну пшеницю на світовому ринку класифікують переважно як другосортну і вважають фуражною. Тому, убачається, найефективніший спосіб підвищити експортні можливості країни - повною мірою гармонізувати вітчизняні вимоги щодо якості зерна з міжнародними. Підвищення класу зерна впливатиме на його вартість не лише на міжнародному, а й на внутрішньому ринку, насамперед постаючи компенсацією додаткових витрат виробника на вирощування зерна вищого класу.

Розглядаючи особливості проведення судових товарознавчих експертиз із визначення вартості викраденої сільськогосподарської продукції, зокрема зернових культур, слід наголосити, що полягають вони в тому, що об'єкти дослідження майже завжди відсутні (не надаються на обстеження). Як вихідні дані для дослідження використовують відомості, що містяться в таких документах:

договір купівлі-продажу та специфікація до нього (показники якості, умови постачання, об'єм партії тощо);

картка аналізу зерна із зазначенням групи, класу зерна та основних показників якості згідно із ДСТУ;

інші документи (сертифікати відповідності, видаткові накладні, товарно-транспортні накладні, платіжні доручення та ін.).

Згідно із законодавством України якість зерна, що виробляється в Україні або ввозиться на iii митну територію, має відповідати державним стандартам та іншим нормативним документам (Pro zerno ta rynok zerna v Ukraini: Zakon Ukrainy, 2002, st. 21). Вимоги до якості експортного зерна фіксуються сторонами в експортному контракті (Hussain, Igbal, Khan, \& Shah, 2020).

Під якістю зерна розуміють сукупність властивостей та ознак (біологічних, фізико-хімічних, технологічних, споживних), які визначають його придатність до використання за призначенням (Usina, 2012, s. 41; Korkuna, Demichkovskyi, \& Tsilnyk, 2019, s. 50). Аналізують якість зерна, грунтуючись на органолептичних (визначення біологічного сорту зерна, що характеризується трьома показниками: колір, запах і смак) та фізико-хімічних (з викорис- 
танням спеціальних методів і лабораторного обладнання) показниках. Згідно із законодавством за результатами лабораторного дослідження видається картка аналізу встановленого зразка із зазначенням групи зерна, класу та основних показників якості відповідно до чинних стандартів.

Основними показниками якості зерна є: колір; запах; смак; вологість; натура; вміст основного зерна та домішок; зараженість і ушкодженість шкідниками; свіжість.
За якістю зернові культури поділяють на класи згідно із національним стандартом, передбаченим для кожного їх виду.

Наприклад, національним стандартом ДСТУ 3768:2019 «Пшениця. Технічні умови» (Pshenytsia. Tekhnichni umovy: DSTU 3768:2019, 2019), що змінив ДСТУ 3768:2010 і обов'язковий до застосування від 10 червня 2019 р., скорочено кількість класів зерна м'якої пшениці до чотирьох, а твердої пшениці визначено п'ять класів (див. табл.).

Таблиця

Показники якості зерна твердої пшениці

\begin{tabular}{|c|c|c|c|c|c|}
\hline \multirow[t]{2}{*}{ Показники } & \multicolumn{5}{|c|}{$\begin{array}{c}\text { Характеристика і норми } \\
\text { для твердої пшениці за класами }\end{array}$} \\
\hline & 1 & 2 & 3 & 4 & 5 \\
\hline Зерна м’якої пшениці, \%, не більше ніж & 4 & 4 & 8 & 10 & Не обмежено \\
\hline Натура, г/л, не менше ніж & 750 & 750 & 730 & 710 & Не обмежено \\
\hline Вологість, \%, не більше ніж & 14,5 & 14,5 & 14,5 & 14,5 & 14,5 \\
\hline Склоподібність, \%, не менше ніж & 70 & 60 & 50 & 40 & Не обмежено \\
\hline Зернова домішка, \%, не більше ніж & 5,0 & 5,0 & 8,0 & 10,0 & 15,0 \\
\hline $\begin{array}{l}\text { Зокрема: } \\
\text { пророслі зерна }\end{array}$ & 1,0 & 1,0 & 3,0 & 3,0 & $\begin{array}{l}\text { У межах зернової } \\
\text { домішки }\end{array}$ \\
\hline Сміттєва домішка, \%, не більше ніж & 2,0 & 2,0 & 2,0 & 5,0 & 5,0 \\
\hline $\begin{array}{l}\text { Зокрема: } \\
\text { мінеральна домішка }\end{array}$ & 0,3 & 0,3 & 0,5 & 0,5 & 1,0 \\
\hline $\begin{array}{l}\text { Зокрема: } \\
\text { галька, шлак, руда }\end{array}$ & 0,15 & 0,15 & 0,2 & 0,3 & $\begin{array}{l}\text { У межах мінеральної } \\
\text { домішки }\end{array}$ \\
\hline зіпсовані зерна & 0,2 & 0,2 & 0,5 & 1,0 & 1,0 \\
\hline $\begin{array}{l}\text { Зокрема: } \\
\text { фузаріозні зерна }\end{array}$ & \multicolumn{5}{|c|}{ У межах зіпсованих зерен } \\
\hline шкідлива домішка & 0,2 & 0,3 & 0,5 & 0,5 & 0,5 \\
\hline $\begin{array}{l}\text { Зокрема: } \\
\text { сажка, ріжки (разом) }\end{array}$ & 0,05 & 0,05 & 0,1 & 0,1 & 0,1 \\
\hline триходесма сива & \multicolumn{5}{|c|}{ Не дозволено } \\
\hline кукіль & \multicolumn{5}{|c|}{ У межах шкідливої домішки } \\
\hline кожен із видів іншого токсичного насіння & 0,05 & 0,05 & 0,05 & 0,05 & 0,1 \\
\hline Сажкове зерно, \%, не більше ніж & 5,0 & 5,0 & 5,0 & 5,0 & 10,0 \\
\hline $\begin{array}{l}\text { Масова частка білка, у перерахунку на суху } \\
\text { речовину, \%, не менше ніж }\end{array}$ & 14,0 & 13,0 & 12,0 & 11,0 & Не обмежено \\
\hline Число падіння, с, не менше ніж & 220 & 200 & 150 & 100 & Не обмежено \\
\hline
\end{tabular}

Крім того, у новому стандарті ДСТУ 3768:2019 підвищено показники якості м'якої пшениці (натури, числа падіння, вмісту зерен злакових культур, сміттєвої домішки, вмісту зіпсованих та фузаріозних зерен, вмісту шкідливої домішки); уперше стандартом рекомендовано визначати вміст зерен, пошкоджених клопом-черепашкою, та силу борошна; упроваджено методики, гармонізовані 3 міжнародними та європейськими стандартами; започатковано перехід на чинні регламенти, інструкції, нормативи тощо; посилено вимоги до продовольчої безпеки і охорони довкілля (Кугра, Lupitko, \& Morhun, 2019, s. 234; Hlupak, Radchenko, Danylchenko, \& Aliiev, 2020, s. 54).

Незалежно від класу зерно «має бути у здоровому стані, не зіпріле та без теплового пошкодження; мати властивий здоровому зерну запах (без затхлого, солодового, пліснявого, гнильного, полинного, сажкового, запаху нафтопродуктів тощо); мати властивий зерну колір; не дозволено зараження пшениці шкідниками зерна» (Pshenytsia. Tekhnichni umovy: DSTU 3768:2019, 2019, p. 4.3). 
Відповідно дефектним вважають зерно зволожене, морозобійне, самозігріте (запарене), запліснявіле, проросле, ушкоджене або заражене шкідниками та організмами.

Якість зерна великою мірою залежить від режиму його зберігання. Будь-які відхилення від стандартів знижують показники якості, що призводить до його здешевлення. При цьому найважливішою умовою зберігання зерна $є$ дотримання допустимої норми вологості. Цей показник залежить від типу, класу зерна, терміну зберігання у сховищі. I, наприклад, за прийнятних умов зберігання зерна на елеваторах становить 12-16 \% відповідно типу культури і терміну знаходження зерна у сховищі. Для злакових, які зберігаються до року, допустима вологість - 14-15 \%, для зернобобових - 15-16 \%. Показник вологості також впливає на кінцеву вартість зернових культур. Так, кожен відсоток відхилення (збільшення) від допустимого показника впливає на загальну якість, фізичну масу і як результат - на закупівельну ціну (у бік зменшення). Крім того, на стан зерна, що в приміщеннях для зберігання, впливають й інші чинники. Неналежні умови можуть спричиняти розвиток шкідливих мікроорганізмів і шкідників, унаслідок чого псуватиметься зерно (Pravylne zberihannia zerna, 2011).

Щодо зерна, яке не відповідає базовим нормам згідно із ДСТУ (вологе, бите, заражене шкідниками, некондиційне тощо), застосовують договірні ціни, передбачаючи знижки за його погіршену якість. Так, при закупівлі сільськогосподарської продукції ТОВ СП «Нібулон» (офіційний сайт: https://www.nibulon.com) у разі вищих за нормативні значення (для зернових культур - вологість $14 \%$, сміттєва домішка $2 \%)$ показників вологості та сміттєвої домішки знижки розраховують за формулою Дюваля (Kalkuliator znyzhok, 2021).

Спосіб зберігання зернових культур залежить переважно від їх фізичних і фізіологічних властивостей. Великими партіями зерно зберігають на елеваторах, механізованих складах, у простих сховищах безтарним способом (насипом) і в тарі (мішках). Завдяки суттєвим перевагам найпоширеніший безтарний спосіб. Переваги його такі: повніше використовуються площа та об'єм зерносховища; більше можливостей для механізованого переміщення зернових мас; полегшується боротьба зі шкідниками зерна; зручніше організовувати контроль за всіма показниками якості зерна та його збереження; зменшуються витрати на тару й переміщення зерна.

У період збирання зернових культур зерно тимчасово можуть зберігати на токах або відкритих майданчиках зерноприймальних підприємств у буртах, коли партії зерна, дотримуючись пев- них правил, складають за межами сховищ, тобто просто неба, у насипі або тарі. Недоліки такого способу зберігання: важко вести спостереження за станом зерна у внутрішніх частинах насипу, аби своєчасно виявляти самозігрівання та розвиток шкідників (Podpriatov, Skaletska, Senkov, \& Khylevych, 2002).

Визначаючи вартість зернових культур у межах товарознавчих досліджень, також обов'язково зважають на умови постачання. Згідно з Офіційними правилами тлумачення торговельних термінів Міжнародної торгової палати - Інкотермс, що регламентують розподіл витрат і ризиків, пов'язаних із транспортуванням товару від продавця до покупця, основними умовами постачання сільськогосподарських, зокрема зернових, культур є:

EXW (франко-завод) - означає повне виконання продавцем своїх зобов'язань 3 постачання партії зерна (ідеться лише про передачу продавцем товару в розпорядження покупця на площах свого підприємства чи в іншому, зазначеному ним, місці (на складі тощо), без здійснення митного очищення (комплексу дій, необхідних для транспортування вантажу і транспортних засобів через кордон України) товару для експорту та завантаження його на будь-який приймальний транспортний засіб. При цьому на продавця покладаються мінімальні обов'язки, а всі витрати й ризики, пов'язані з перевезенням товару з площ продавця до місця призначення, приймає на себе покупець;

СРТ (фрахт / перевезення оплачено до) здійснення продавцем постачання товару шляхом його передання перевізнику (ідеться про будьякий вид транспорту, зокрема й мультимодальні (змішані) перевезення), призначеному ним самим, з оплатою витрат на перевезення товару до визначеного місця призначення. Також продавець зобов'язаний здійснити митне очищення товару для експорту. При цьому покупець бере на себе всі ризики та витрати, які можуть виникнути після здійснення постачання товару;

FOB (франко-борт) - зазначені умови стосуються лише перевезення товару морським чи внутрішнім водним транспортом і передбачають зобов'язання продавця доставити товар в порт i погрузити на вказане покупцем судно власним коштом, після чого всі витрати та ризики покладаються на покупця. При цьому продавець також має здійснити митне очищення товару для експорту.

Слід зазначити, що умови постачання суттєво впливають на кінцеву вартість партії зернових культур. Прикладом цього є моніторинг внутрішніх ринкових цін на кукурудзу (див. рис.), що за- 
свідчив найнижчу для покупця ціну на умовах придбання EXW (франко-завод), а найвищу СРТ (фрахт / перевезення оплачено до). під час судової товарознавчої експертизи в контексті застосування спеціальних знань. Класифікацію зернових культур за призначенням уточне-

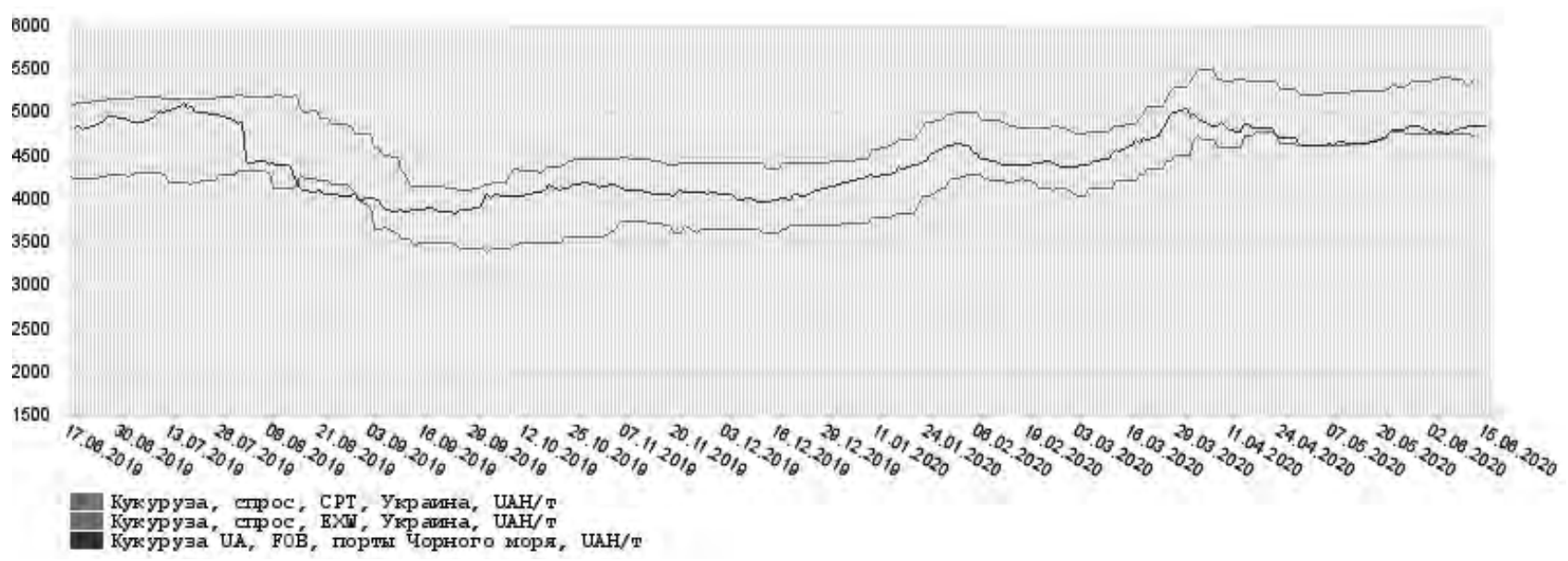

Рис. Моніторинг ринкових цін на кукурудзу на внутрішньому ринку залежно від умов її постачання, грн/т (Kukurudza-UA, tsina, 2021)

Визначаючи вартість зернових культур, зважають й на вид ринкової ціни: оптова, роздрібна чи закупівельна; контрактна, біржова чи аукціонна; ціна пропозиції, попиту чи реалізації. При цьому беруть до уваги місце реалізації зернових: на елеваторах чи в портах.

На ціноутворенні зернових культур також відбивається співвідношення попиту та пропозиції, зумовлене зовнішніми (ціни на світових біржах, співвідношення запасів основних експортерів до їх використання, індекс світових цін, урожайність у різних країнах, погодно-кліматичні умови) та внутрішніми (економічні коливання, курс долара на ринку, площі посівів, обсяг виробництва, погодно-кліматичні умови, які великою мірою впливають на кількісний та якісний склад урожаю) чинниками.

Традиційно й цілком об’єктивно на ціноутворенні зернових культур позначається сезонність продажів. Найнижча ціна в перший місяць збирання врожаю (для кожної культури свої терміни). Цей період вважають фінансово найменш сприятливим для продажу. Закономірно вартість зернових культур суттєво підвищується з нового календарного року і до початку літа, а знижується 3 кінця літа до початку зими. Загальним принципом ціноутворення у цьому сенсі $є$ підвищення ціни реалізації на зерно тоді, коли зменшуються запаси на ринку, та їі зниження, коли надходить пропозиція свіжого урожаю. Як видно з графіку моніторингу цін (див. рис.), фінансово найбільш сприятливий період для продажу кукурудзи - кінець березня - початок квітня.

\section{Наукова новизна}

Систематизовано і обгрунтовано основні особливості визначення вартості зернових культур но двома позиціями - зерно для експортування та насіння (посівний матеріал).

\section{Висновки}

1. Нормативно-правову базу, що врегульовує обіг сільськогосподарської, зокрема й зернової, продукції, становлять закони України та підзаконні нормативно-правові акти, а систему технічного регулювання - національні стандарти України, певною мірою гармонізовані з міжнародними вимогами, технічні регламенти, процедури підтвердження відповідності щодо конкретного виду зерна або насіння, що потребують подальшого узгодження. Наприклад, через те що в Україні та за кордоном різняться показники залишкової кількості радіонуклідів, токсичних речовин, пестицидів, мікотоксинів у продовольчій сировині, у разі експортування зернових культур вимоги до показників їх якості обумовлюються й детально описуються у контракті і поширюються конкретно на закупівельну партію.

2. Проаналізовано сучасні класифікації зернових культур; при цьому класифікацію за призначенням уточнено двома позиціями - зерно для експортування та насіння (посівний матеріал).

3. 3'ясовано особливості визначення вартості зернових культур під час судової товарознавчої експертизи, що грунтуються на застосуванні спеціальних товарознавчих і інших знань.

4. Схарактеризовано та систематизовано чинники, які зумовлюють особливості визначення вартості зернових культур під час судової товарознавчої експертизи, як-от: показники якості, умови договору постачання та об'єм партії, умови і територіальне розташування місця постачання, умови зберігання, а також співвідношення попиту та пропозиції, зважаючи на світові ціни, урожай- 
ність, сезонність продажу, погодно-кліматичні умови тощо.

5. У процесі викладу основного матеріалу сформульовано деякі пропозиції і практичні ре- комендації щодо визначення вартості зернових культур під час судової товарознавчої експертизи, які можуть становити підгрунтя для розроблення відповідних методик і методичних рекомендацій.

\section{References}

Buzyna, S. O., \& Kravchenko, R. V. (2020). Teoretychni ta metodolohichni aspekty sudovoi tovaroznavchoi ekspertyzy. Molodyi vchenyi, 11 (87), 272-275 [in Ukrainian].

DOI: https://doi.org/10.32839/2304-5809/2020-11-87-58.

FAO. (2020, Jul.). Crop Prospects and Food Situation. Quarterly Global Report, 2, Rome.

DOI: https://doi.org/10.4060/ca9803en.

Grain crop drying, handling and storage (2011). Rural structures in the tropics: design and development. Ch. 16, Rome. Retrieved from http://www.fao.org/3/i2433e/i2433e00.htm.

Havrylenko, O. S., Khomitska, O. A., \& Zahorulko, O. V. (2016). Otsinka vplyvu mikrobiolohichnykh protsesiv pid chas zberihannia zerna yaroi pshenytsi. Visnyk Poltavskoi derzhavnoi ahrarnoi akademii, 4, 31-35 [in Ukrainian]. DOI: https://doi.org/10.31210/visnyk2016.04.05.

Herman, M. M., \& Marenych, M. M. (2013). Yakist zerna pshenytsi miakoi ozymoi ta shliakhy yii pidvyshchennia. Visnyk Poltavskoi derzhavnoi ahrarnoi akademii, 4, 19-22 [in Ukrainian]. DOI: https://doi.org/10.31210/visnyk2013.04.04.

Heyne, E. G. (2020). Grain crops. DOI: https://doi.org/10.1036/1097-8542.296800.

Hlupak, Z. I. (2017). Osoblyvosti standartyzatsii pshenytsi v Ukraini ta SShA. Visnyk Sumskoho natsionalnoho ahrarnoho universytetu. Ahronomiia i biolohiia, 9 (34), 56-61 [in Ukrainian].

Hlupak, Z. I., Radchenko, M. V., Danylchenko, O. M., \& Aliiev Simur. (2020). Osnovni zminy v novomu standarti na pshenytsiu. Tavriiskyi naukovyi visnyk, 111, 49-54 [in Ukrainian]. DOI: https://doi.org/10.32851/2226-0099.2020.111.6.

Hussain, A., Igbal, A., Khan, Z. H., \& Shah, F. (2020). Introductory Chapter: Recent Advances in Grain Crops Research. DOI: https://doi.org/10.5772/intechopen.90701.

Hordiienko, H. S., \& Likhonina, H. O. (2008). Rozdil 1. Zernoboroshniani ta khlibobulochni vyroby. Brovko, O. H., Bulhakova, O. V., Hordiienko, H. S., Diatlov, V. V., Kvasnykov, A. A., Kozlov, A. P. ... Temnokhud, E. O., Tovaroznavstvo. Prodovolchi tovary: navch. posib. dlia stud. vyshch. navch. zakladiv osvity 1 ta 2 rivniv akredytatsii (s. 4-67). Donetsk: DonNUET. 619 s. [in Ukrainian].

Kalkuliator znyzhok. NIBULON: ofits. sait. (2021). Retrieved from https://www.nibulon.com/data/zakupivlya-silgospprodukcii/kalkulyator-znizhok.html [in Ukrainian].

Korkuna, O., Demichkovskyi, A., Tsilnyk, O., Bordun, O., \& Pikhur, O. (2019) Tovaroznavstvo: navch.-metod. posib. dlia stud. Lviv: LDUFK im. I. Boberskoho, 200 s. [in Ukrainian].

Kotenko, V. (2020). Osoblyvosti formuvannia popytu u modeliuvanni lantsiuhiv postavok zernovykh kultur. Suchasni tekhnolohii v mashynobuduvanni ta transporti, 2 (15), 35-40 [in Ukrainian].

DOI: https://doi.org/10.36910/automash.v2i15.390.

Kukurudza-UA, tsina. Analitychne ahentstvo AGRICULTURE: ofits. sait. (2021). Uziato z http://www.agriagency.com.ua/ prices/index.php?period $=365 \&$ data $=3 \&$ curr $=1$ [in Ukrainian].

Kyrpa, M. Ya., Lupitko, O. I., \& Morhun, O. V. (2019). Novyi standart na zerno pshenytsi: osoblyvosti rozroblennia ta zastosuvannia. Zernovi kultury. Dnipro, 3 (2), 233-239 [in Ukrainian]. DOI: https://doi.org/10.31867/2523-4544/0082.

Lesniak, O. Yu. (2019). Urakhuvannia faktoru pryrodnykh resursiv pid chas vyznachennia bahatofaktornoi produktyvnosti silskoho hospodarstva. Ekonomika pryrodokorystuvannia ta okhorony navkolyshnoho seredovyshcha, 48 (2), 171-174 [in Ukrainian]. DOI: https://doi.org/10.32843/bses.48-62.

Liapun, N. M., \& Kovalenko, N. V. (2020). Identyfikatsiia tovariv ta vyznachennia falsyfikatsii produktsii pry provedenni sudovoi tovaroznavchoi ekspertyzy. Molodyi vchenyi, 8 (84), 240-243 [in Ukrainian]. DOI: https://doi.org/10.32839/2304-5809/2020-8-84-48.

Nasinnia silskohospodarskykh kultur. Sortovi ta posivni yakosti. Tekhnichni umovy: DSTU 2240-93. (1994), Kyiv: Derzhstandart Ukrainy, $80 \mathrm{~s}$. Uziato z http://ksv.do.am/GOST/DSTY_ALL/DSTY1/dsty_2240-93.pdf [in Ukrainian].

Olefir, Yu. S. (2020). Mozhlyvosti sudovoi tovaroznavchoi ekspertyzy v mezhakh kryminalnoho provadzhennia. Kryminalistychnyi visnyk, 2 (32), 46-52 [in Ukrainian].

DOI: https://doi.org/10.37025/1992-4437/2019-32-2-46.

Podpriatov, H. I., Skaletska, L. F., Senkov, A. M., \& Khylevych, V. S. (2002) Zberihannia i pererobka produktsii roslynnytstva: navch. posib. Kyiv: Meta. 495 s. [in Ukrainian].

Porivnialnyi analiz vymoh svitovoho spivtovarystva ta Ukrainy shchodo pokaznykiv bezpeky. (2021). Uziato z https://www. gcsms.com.ua/arkhiv-novin/238-porivnialnuj-analiz-vumog-svitovogo-spivtovarustva-ta-ukrainu-shodo-pokaznukiv-bezpeku [in Ukrainian]. 
Pravylne zberihannia zerna $v$ zernoskhovyshchi. Uziato z https://ambarexport.ua/blog/storage-of-grain [in Ukrainian].

Pro derzhavnu pidtrymku silskoho hospodarstva Ukrainy: Zakon Ukrainy № 1877-IV. (2004). Uziato z https://zakon.rada. gov.ua/laws/show/1877-15\#Text [in Ukrainian].

Pro derzhavne rehuliuvannia importu silskohospodarskoi produktsii: Zakon Ukrainy № 468/97-VR. (1997). Uziato z https://zakon.rada.gov.ua/laws/show/468/97-\%D0\%B2\%D1\%80\#Text [in Ukrainian].

Pro nasinnia i sadyvnyi material: Zakon Ukrainy № 411-IV. (2002). Uziato z https://zakon.rada.gov.ua/laws/show/41115\#Text [in Ukrainian].

Pro zerno ta rynok zerna v Ukraini: Zakon Ukrainy № 37-IV. (2002). Uziato z https://zakon.rada.gov.ua/laws/show/37-15 [in Ukrainian].

Pshenytsia. Tekhnichni umovy: DSTU 3768:2019. (2019), Kyiv: DP «UkrNDNTs». 19 s. Uziato z http://online.budstandart. com/ua/catalog/doc-page.html?id_doc=82765 [in Ukrainian].

Shakalii, S. M. (2013). Urozhainist ta yakist zerna pshenytsi miakoi ozymoi zalezhno vid mineralnoho zhyvlennia. Visnyk Poltavskoi derzhavnoi ahrarnoi akademii, 4, 145-148 [in Ukrainian]. DOI: https://doi.org/10.31210/visnyk2013.04.36.

Shytova, L. V., \& Sobakar, Ye. M. (2019). Aktualni pytannia sudovoi tovaroznavchoi ekspertyzy: defekty tovariv ta yikh vplyv na vyznachennia vartosti. Molodyi vchenyi, 8 (72), 295-299 [in Ukrainian]. DOI: https://doi.org/10.32839/2304-5809/2019-8-72-63.

Syrotiuk, A. M. (2010). Upravlinnia yakistiu produktsii APK yak kliuchovyi faktor pokrashchennia yii konkurentospromozhnosti na svitovomu rynku. Zbirnyk naukovykh prats Tavriiskoho derzhavnoho ahrotekhnolohichnoho universytetu (ekonomichni nauky), 2 (10), 335-338 [in Ukrainian].

Ukraina protiahom desiaty rokiv rekordno narostyla eksport zernovykh (2020). Uziato z https://www.ukrinform.ua/rubric-economy/2882799-ukraina-protagom-10-rokiv-rekordno-narostila-eksport-zernovih.html [in Ukrainian].

Usina, A. I. (2012). Konspekt lektsii $z$ dystsypliny «Tovaroznavstvo». Kharkiv: KhNAMH. 196 s. [in Ukrainian].

Yurkovska, V., Ovsiannykova, L., Yevdokymova, H., Valevska, L., \& Sokolovska, O. (2019). Vplyv riznykh umov zberihannia na yakist zerna prosa. Scientific Works, 82 (2), 88-95 [in Ukrainian].

DOI: https://doi.org/10.15673/swonaft.v82i2.1184.

Yaki vymohy do eksportnoi pshenytsi. (2021). Uziato z https://sojam.ua/vimogi-eksportnoj-pshenici/ [in Ukrainian].

Zaiats, Ya. I., Yarovyi, O. D., \& Bednarchuk, M. S. (2019). Aktualni problemy vitchyznianoi sudovoi tovaroznavchoi ekspertyzy. Visnyk Lvivskoho torhovelno-ekonomichnoho universytetu. Tekhnichni nauky, 22, 90-95 [in Ukrainian]. DOI: https://doi.org/10.36477/2522-1221-2019-22-15.

Zhukov, O. V., \& Ponomarenko, S. V. (2018). Prostorovo-chasova dynamika urozhainosti zernovykh ta zernobobovykh kultur u Poltavskii oblasti. Visnyk Poltavskoi derzhavnoi ahrarnoi akademii, 1, 55-62 [in Ukrainian].

DOI: https://doi.org/10.31210/visnyk2018.01.08.

\section{Список використаних джерел}

Бузина, С. О., \& Кравченко, Р. В. (2020). Теоретичні та методологічні аспекти судової товарознавчої експертизи. Молодий вчений, 11 (87), 272-275.

DOI: https://doi.org/10.32839/2304-5809/2020-11-87-58.

FAO. (2020, Jul.). Crop Prospects and Food Situation. Quarterly Global Report, 2, Rome. DOI: https://doi.org/10.4060/ca9803en.

Grain crop drying, handling and storage (2011). Rural structures in the tropics: design and development. Ch. 16, Rome. Retrieved from http://www.fao.org/3/i2433e/i2433e00.htm.

Гавриленко, О. С., Хоміцька, О. А., \& Загорулько, О. В. (2016). Оцінка впливу мікробіологічних процесів під час зберігання зерна ярої пшениці. Вісник Полтавської державної аграрної академії, 4, 31-35. DOI: https://doi.org/10.31210/visnyk2016.04.05.

Герман, М. М., \& Маренич, М. М. (2013). Якість зерна пшениці м'якої озимої та шляхи ії підвищення. Вісник Полтавської державної аграрної академії, 4, 19-22.

DOI: https://doi.org/10.31210/visnyk2013.04.04.

Heyne, E. G. (2020). Grain crops. DOI: https://doi.org/10.1036/1097-8542.296800.

Глупак, 3. І. (2017). Особливості стандартизації пшениці в Україні та США. Вісник Сумського національного аграрного університету. Агрономія і біологія, 9 (34), 56-61.

Глупак, 3. І., Радченко, М. В., Данильченко, О. М., \& Алієв Сімур. (2020). Основні зміни в новому стандарті на пшеницю. Таврійський науковий вісник, 111, 49-54.

DOI: https://doi.org/10.32851/2226-0099.2020.111.6.

Hussain, A., Igbal, A., Khan, Z. H., \& Shah, F. (2020). Introductory Chapter: Recent Advances in Grain Crops Research. DOI: https://doi.org/10.5772/intechopen.90701.

Гордієнко, Г. С., \& Ліхоніна, Г. О. (2008). Розділ 1. Зерноборошняні та хлібобулочні вироби. Бровко, О. Г., Булгакова, О. В., Гордієнко, Г. С., Дятлов, В. В., Квасников, А. А., Козлов, А. П. ... Темнохуд, Е. О., Товарознавство. Продовольчі товари: навч. посіб. для студ. вищ. навч. закладів освіти 1 та 2 рівнів акредитації (с. 4-67). Донецьк: ДонНУЕТ. 619 с.

Калькулятор знижок. НІБУЛОН: офіц. сайт. (2021). Узято з https://www.nibulon.com/data/zakupivlya-silgospproduk- 
cii/kalkulyator-znizhok.html.

Коркуна, О., Демічковський, А., Цільник, О., Бордун, О., \& Піхур, О. (2019) Товарознавство: навч.-метод. посіб. для студ. Львів: ЛДУФК ім. І. Боберського, 200 с.

Котенко, В. (2020). Особливості формування попиту у моделюванні ланцюгів поставок зернових культур. Сучасні технології в машинобудуванні та транспорті, 2 (15), 35-40.

DOI: https://doi.org/10.36910/automash.v2i15.390.

Кукурудза-UA, ціна. Аналітичне агентство AGRICULTURE: офіц. сайт. (2021). Узято з http://www.agriagency.com. ua/prices/index.php?period $=365 \&$ data $=3 \&$ curr $=1$.

Кирпа, М. Я., Лупітько, О. І., \& Моргун О. В. (2019). Новий стандарт на зерно пшениці: особливості розроблення та застосування. Зернові культури. Дніпро, 3 (2), 233-239.

DOI: https://doi.org/10.31867/2523-4544/0082.

Лесняк, О. Ю. (2019). Урахування фактору природних ресурсів під час визначення багатофакторної продуктивності сільського господарства. Економіка природокористування та охорони навколишнього середовища, 48 (2), $171-174$. DOI: https://doi.org/10.32843/bses.48-62.

Ляпун, Н. М., \& Коваленко, Н. В. (2020). Ідентифікація товарів та визначення фальсифікації продукції при проведенні судової товарознавчої експертизи. Молодий вчений, 8 (84), 240-243.

DOI: https://doi.org/10.32839/2304-5809/2020-8-84-48.

Насіння сільськогосподарських культур. Сортові та посівні якості. Технічні умови: ДСТУ 2240-93. (1994), Київ: Держстандарт України, 80 с. Узято 3 http://ksv.do.am/GOST/DSTY_ALL/DSTY1/dsty_2240-93.pdf.

Олефір, Ю. С. (2020). Можливості судової товарознавчої експертизи в межах кримінального провадження. Криміналістичний вісник, 2 (32), 46-52.

DOI: https://doi.org/10.37025/1992-4437/2019-32-2-46.

Подпрятов, Г. І., Скалецька, Л. Ф., Сеньков, А. М., \& Хилевич, В. С. (2002) Зберігання і переробка продукції рослинництва: навч. посіб. Київ: Мета. 495 с.

Порівняльний аналіз вимог світового співтовариства та Украӥни щодо показників безпеки. (2021). Узято з httрs:// www.gcsms.com.ua/arkhiv-novin/238-porivnialnuj-analiz-vumog-svitovogo-spivtovarustva-ta-ukrainu-shodo-pokaznukiv-bezpeku.

Правильне зберігання зерна в зерносховищі. Узято з https://ambarexport.ua/blog/storage-of-grain.

Про державну підтримку сільського господарства України: Закон України № 1877-IV. (2004). Узято з https://zakon. rada.gov.ua/laws/show/1877-15\#Text.

Про державне регулювання імпорту сільськогосподарської продукції: Закон України № 468/97-ВР. (1997). Узято 3 https://zakon.rada.gov.ua/laws/show/468/97-\%D0\%B2\%D1\%80\#Text.

Про насіння і садивний матеріал: Закон України № 411-IV. (2002). Узято з https://zakon.rada.gov.ua/laws/show/41115\#Text.

Про зерно та ринок зерна в Україні: Закон України № 37-IV. (2002). Узято з https://zakon.rada.gov.ua/laws/show/37-15.

Пшениця. Технічні умови: ДСТУ 3768:2019. (2019), Київ: ДП «УкрНДНЦ». 19 с. Узято з http://online.budstandart. com/ua/catalog/doc-page.html?id_doc $=82765$.

Шакалій С. М. (2013). Урожайність та якість зерна пшениці м’якої озимої залежно від мінерального живлення. Вісник Полтавської державної аграрної академії, 4, 145-148.

DOI: https://doi.org/10.31210/visnyk2013.04.36.

Шитова, Л. В., \& Собакарь, Є. М. (2019). Актуальні питання судової товарознавчої експертизи: дефекти товарів та їх вплив на визначення вартості. Молодий вчений, 8 (72), 295-299. DOI: https://doi.org/10.32839/2304-5809/2019-8-72-63.

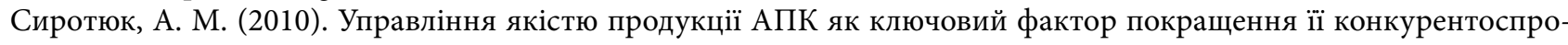
можності на світовому ринку. Збірник наукових праць Таврійського державного агротехнологічного університету (економічні науки), 2 (10), 335-338.

Україна протягом десяти років рекордно наростила експорт зернових (2020). Узято з https://www.ukrinform.ua/ rubric-economy/2882799-ukraina-protagom-10-rokiv-rekordno-narostila-eksport-zernovih.html.

Усіна, А. І. (2012). Конспект лекцій з дисципліни «Товарознавство». Харків: ХНАМГ. 196 с.

Юрковська, В., Овсянникова, Л., Євдокимова, Г., Валевська, Л., \& Соколовська, О. (2019). Вплив різних умов зберігання на якість зерна проса. Scientific Works, 82 (2), 88-95.

DOI: https://doi.org/10.15673/swonaft.v82i2.1184.

Які вимоги до експортної пшениці. (2021). Узято з https://sojam.ua/vimogi-eksportnoj-pshenici/.

Заяць, Я. І., Яровий, О. Д., \& Беднарчук, М. С. (2019). Актуальні проблеми вітчизняної судової товарознавчої експертизи. Вісник Львівського торговельно-економічного університету. Технічні науки, 22, 90-95. DOI: https://doi.org/10.36477/2522-1221-2019-22-15.

Жуков, О. В., \& Пономаренко, С. В. (2018). Просторово-часова динаміка урожайності зернових та зернобобових культур у Полтавській області. Вісник Полтавської державної аграрної академї, 1, 55-62. DOI: https://doi.org/10.31210/visnyk2018.01.08. 


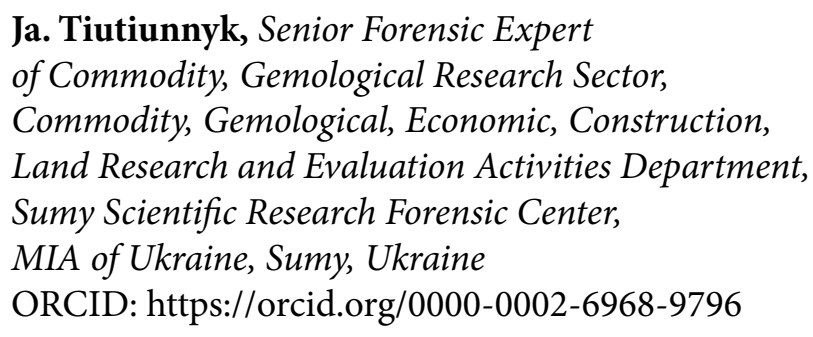

\title{
DETERMINING THE COST OF GRAIN CROPS DURING FORENSIC COMMODITY EXAMINATION
}

\begin{abstract}
The purpose of the article is to develop proposals and practical recommendations for determining the cost of grain crops during forensic commodity examination based on a comprehensive analysis of theoretical provisions, normative legal acts and systems of technical regulation. Methodology. The reliability of the results and conclusions is ensured through a system of general scientific and specific methods of discovery. The comparative legal method is used to investigate the main approaches to regulation of the grain crops circulation and quality; the systemic structural method is employed to determine the essence of the concept and characteristics of grain quality; the analysis and synthesis methods supported the identification and research of the features of grain crop classification by various features; the method of generalization was used to identify and characterize the factors affecting the cost of grain, which the expert must take into account for the purposes of forensic commodity assessment; and analytical methods allowed for a formulation of conclusions of the study. Scientific novelty. The main features of determining the cost of grain crops during the forensic commodity assessment in the context of the application of special knowledge are systematized and substantiated. Classification of grain crops by purpose is clarified by two positions - grain for export and seeds (sowing material). Conclusions. The regulatory framework on the circulation of agricultural, in particular grain, products, comprises the laws of Ukraine and regulations, and the system of technical regulations includes the national standards of Ukraine, to a certain extent harmonized with international requirements, technical regulations, and verification procedures concerning specific types of grain or seeds that require further harmonization. The peculiarities of determining the cost of grain crops during the forensic commodity examination are determined through the application of specific commodity expertise and other knowledge. The article characterizes and systematizes factors that determine the peculiarities of determining the cost of grain crops during the forensic commodity examination. The main part of the article includes proposals and practical recommendations for determining the value of grain crops during the forensic commodity examination, which may be the basis for the development of relevant techniques and methodological recommendations.

Keywords: forensic commodity examination; specialized knowledge; specialized commodity expert knowledge; agricultural products; grain crops; grain quality indicators; sowing material; classification; supply conditions; grain storage; cost.
\end{abstract}

\author{
Я. М. Тютюнник, старший судебный эксперт \\ сектора товароведческих и геммологических исследований \\ отдела товароведческих, геммологических, экономических, \\ строительных, земельных исследований и оченочной деятельности, \\ Сумской научно-исследовательский экспертно-криминалистический \\ иентр МВД Украиньи, г. Сумьь \\ ORCID: https://orcid.org/0000-0002-6968-9796
}

\section{ОСОБЕННОСТИ ОПРЕДЕЛЕНИЯ СТОИМОСТИ ЗЕРНОВЫХ КУЛЬТУР В ХОДЕ СУДЕБНОЙ ТОВАРОВЕДЧЕСКОЙ ЭКСПЕРТИЗЫ}

\footnotetext{
Цель статьи заключается в разработке на основе комплексного анализа теоретических положений, нормативно-правовых актов и систем технического регулирования предложений и практических рекомендаций по определению стоимости зерновых культур в ходе судебной товароведческой экспертизы. Методология. Достоверность полученных результатов и выводов обеспечена комплексом общенаучных и специальных методов познания. Так, сравнительно-правовым методом исследованы основные подходы к нормативной регламентации особенностей обращения зерновых культур, нормирования их качества; системно-структурным определена сущность понятия и характеристики качества зерна; методами анализа и синтеза выявлены и исследованы особенности классификации зерновых культур по разным признакам; с помощью метода обобщения выделены и охарактеризованы факторы, которые влияют на стоимость зерна и которые эксперт должен учитывать, решая задачи судебной товароведческой экспертизы; аналитические методы позволили сформу-
} 
лировать выводы по результатам исследования. Научная новизна. Систематизированы и обоснованы основные особенности определения стоимости зерновых культур в ходе судебной товароведческой экспертизы в контексте применения специальных знаний. Классификация зерновых культур по их назначению уточнена двумя позициями - зерно для экспорта и семена (посевной материал). Выъводы. Нормативно-правовую базу, регулирующую оборот сельскохозяйственной, в том числе зерновой, продукции, составляют законы Украины и подзаконные нормативно-правовые акты, а систему технического регулирования - национальные стандарты Украины, что в определенной степени гармонизированы с международными требованиями, технические регламенты, процедуры подтверждения соответствия по конкретному виду зерна или семян, требующие дальнейшего согласования. Выявлены особенности определения стоимости зерновых культур в ходе судебной товароведческой экспертизы, предполагающие применение специальных товароведных и других знаний. Охарактеризованы и систематизированы факторы, которые обусловливают особенности определения стоимости зерновых культур в ходе судебной товароведческой экспертизы. В процессе изложения основного материала сформулированы некоторые предложения и практические рекомендации по определению стоимости зерновых культур в ходе судебной товароведческой экспертизы, которые могут быть основой для разработки соответствующих методик и методических рекомендаций.

Ключевые слова: судебная товароведческая экспертиза; специальные знания; специальные товароведческие знания; сельскохозяйственная продукция; зерновые культуры; показатели качества зерна; посевной материал; классификация; условия поставки; хранение зерна; стоимость. 